\title{
THE PREVENTION OF CORRUPTION RISK THROUGH THE IMPROVEMENT OF OPEN SELECTION SYSTEM FOR TOP LEADERSHIP POSITION IN LOCAL GOVERNMENT
}

\author{
ARTICLE INFORMATION \\ Article history: \\ Received July 31, 2016 \\ Revised Nov 14, 2017 \\ Accepted Dec 19, 2017 \\ JEL Classifications \\ K42; H79 \\ Key Words: \\ Promotion; \\ Top Leadership Position; \\ State Civil Service \\ Commission (KASN)
}

\section{DOI:}

10.21532/apfj.001.17.02.02.09

\author{
Abdul Aziz \\ Abdulazizbasri94@gmail.com
}

\begin{abstract}
Through the Regulation of the Minister of State Apparatus Empowerment (Permenpan) no 13 of 2014, the government has changed and imposed a new system in the placement of the top leadership position by applying an open promotion system. However, this system is still considered providing space for the risk of corruption, especially in local governments. The main purpose of this study is to review the rules underlying the implementation of open promotion in local government and provide an idea for the improvement of this system. This study uses a qualitative approach in which the data collection is conducted through interviews, observations and documentation. The results of this study indicate that the procedures and mechanisms of the implementation of open promotion for the top leadership position in local governments still provide spaces for corruption, such as in the formation of selection committees, mechanisms in determining the selection results, and monitoring and evaluation mechanisms. In addition, it is necessary to integrate the implementation of promotion of the top leadership positions, both in central and in local governments. In conclusion, a number of inputs that can be put forward include the enhancement of the function of the State Civil Service Commission (better known in Indonesia as KASN) in monitoring the implementation of open promotion of top leadership position in local government. As a preventive measure, the implementation of open promotion can be developed through electronic systems.
\end{abstract}

\section{INTRODUCTION}

Open selection and promotion system for the top leadership position has become a hot topic being discussed by various parties. This is because some local governments, both regency/municipality and province have just had new Region Heads through direct election conducted 
simultaneously last December. As usual, the new Region Head will also make replacement of the officials who become his subordinates. For layman, it seems too late, but when it is viewed carefully, this is in accordance with the applicable regulations, in which the new Region Head cannot replace the officials under him for approximately 6 months from the inauguration and if he wants to make replacement of the position, it must be conducted through open promotion and selection system. This change is a form of the implementation of bureaucratic reform in Indonesia by applying open selection and promotion system, especially for the positions at the echelon I and II as Top Leadership Positions (better known in Indonesia as Jabatan Pimpinan Tinggi or JPT) in both central and regional levels. This is in accordance with the mandate of Law Number 5 of 2014 that must be implemented as a form of reform in the personnel management or state civil apparatus management.

When viewed thoroughly, especially on the local government, the system applied in the placement of a position is the prerogative of the Region Head, although in fact, this has been preregulated in Government Regulation No. 13 of 2002 concerning the appointment of employees in structural positions in which the placement of the echelon positions in local government must be based on the approval of Advisory Board for Position and Rank (better known in Indonesia as Baperjakat). However, at the implementation stage, collusion, corruption, and nepotism practices still cannot be eliminated. This is because the composition of Advisory Board for Position and Rank (Baperjakat) are all filled by civil servants, or not from professionals, so that the system can be set by the Region Head. In addition, it is also supported by the weak supervision system implemented by either internal or external parties, executive or legislative so that the appointment of echelon officials is entirely in the hands of the Region Head. The direct perceived negative impact is the existence of dynastic politics, that is, the politics of repayment which causes the obstruction of development goals, because the promotion and selection system for the position is not in accordance with the required competencies.

Open selection and promotion system for top leadership positions has the main function to avoid collusion, corruption, and nepotism practices and to get qualified states civil apparatus, because top leadership position is a position that has a high strategic function and position. Deputy of Human Resources of the Ministry of State Apparatus Empowerment and Bureaucratic Reform (PANRB) Setiawan Wangsaatmaja reveals that of all officials in structural positions, about 12 thousand people $(0.27 \%)$ occupy top leadership positions (JPT). The positions consist of echelon I and II officials, either at ministries, institutions or in local government.

In general, there is no significant difference in the implementation of open promotion and selection system between central government and local government, especially for top leadership positions. In the central government the selection process begins with the formation of selection committee proposed by the authorized official with the consideration and approval of the State Civil Service Commission (KASN) with the composition of at least 5 people and a maximum of 9 people with the provision of $45 \%$ coming from professionals. The next step continues consecutively starting from announcements, administrative selection, to competency selection. Likewise, the implementation of top leadership position selection in local government with criteria of JPT Pratama is also conducted with the same mechanism. But the concern is for the JPT Pratama which is equivalent to the echelon II position in which its implementation does not require the direct approval from the president or KASN. In this case, the open selection is carried out 
for the formality only, thus resulting in the collusion, corruption, and nepotism practices. Therefore, there should be improvement in the open selection and promotion system not only in central government but also in local government.

As a matter of consideration, the top leadership position in the local government has a strategic role in the achievement of development and service delivery. In 2016 the focus of development implementation was prioritized and directed to the local government, so it certainly requires individuals who have adequate competence and can synchronize with the central government related to the programs and activities to be implemented. Based on this consideration, the purpose of this study is to provide reviews and ideas on improving an open selection system for top leadership position (JPT) in preventing the risk of corruption at the local government level.

\section{METHOD}

\section{Promotion}

According to Rivai (2013: 199), promotion occurs when an employee is transferred from one job position to another job position with higher payments, responsibilities or levels. In its implementation, Siagian (2011: 170) divides the two main criteria in considering a person to be promoted, that is, work performance and seniority. In order for the objectivity requirements to be met and to ensure that the promotion of employees has a positive impact on the organization and the spirit of the whole employees, the most appropriate approach in employee promotion is to combine work performance and seniority. In such cases, the risk factors can only be minimized because they cannot be completely eliminated.

\section{Competency-Based Selection}

Competency-based approach can basically be applied in all operational functions of HR management, including in the selection.
According to Marwansyah (2012: 44), competency-based selection method focuses more on performance than on job content. Technical competency can be measured through qualifications, while behavioral competency can be measured through a number of interview processes or through an assessment center.

\section{Top Leadership Position (JPT)}

Law No. 5 of 2014, Article 19 explains that the top leadership position in Indonesia consists of upper, middle and lower. The higher top leadership position is the head of non-ministerial government institution. The middle top leadership position consists of the secretary general of the ministry, the secretary of the ministry, the chief secretary, the secretary general of the state secretariat, the secretary general of the non-structural institution, the director general, the deputy, the inspector general, the chief inspector, the head of agency, the ministerial expert staff, the Head of the Presidential Secretariat, the Head of the Vice President Secretariat, the Presidential Military Secretary, the Head of the Secretariat of the Presidential Advisory Council, the provincial secretary, and other equivalent positions. The lower top leadership position consists of the director, the bureau chief, the deputy assistant, the secretary of the directorate general, the secretary of the inspectorate general, the secretary of agency head, the head of the center, the inspector, the head of the great hall, the assistant of provincial secretariat, the secretary of regency or municipality, the head of provincial agency, the secretary of the Regional House of Representatives, and other equivalent positions. 
Table 1

Echelon Position Adjustment

\begin{tabular}{|c|c|l|}
\hline No & Position & \multicolumn{1}{c|}{ Echelon } \\
\hline 1 & $\begin{array}{c}\text { Higher Top Leadership } \\
\text { Position }\end{array}$ & $\begin{array}{l}\text { The Head of Non-Ministerial Government } \\
\text { Institution }\end{array}$ \\
\hline 2 & $\begin{array}{c}\text { Middle Top Leadership } \\
\text { Position }\end{array}$ & Echelon Ia and Ib \\
\hline 3 & $\begin{array}{c}\text { Lower Top Leadership } \\
\text { Position }\end{array}$ & Echelon II \\
\hline
\end{tabular}

Certain higher and middle top leadership positions may come from non-civil servants with the approval of the President in which the placement is conducted in open and competitive system as stipulated in the Presidential Decree. The top leadership positions can be filled by soldiers of the Indonesian National Army and members of the Police of the Republic of Indonesia after withdrawing from the active service, if required, and in accordance with the competencies established through open and competitive process. The top leadership position in certain Government Agencies can be filled by soldiers of the Indonesian National Army and members of the Police of the Republic of Indonesia in accordance with competence under the provisions of legislation.

\section{The Placement of Top Leadership Position}

Based on the provisions of Articles 108 and 109 of Law No 5 of 2014, the placement higher and middle top leadership positions in the ministries, the secretariats of state institutions, non-structural institutions and regional agencies is conducted openly and competitively among the civil servants based on the requirements of competence, qualifications, training, job track record, integrity and other requirements in accordance with the provisions of laws and regulations that are conducted at the national level. Meanwhile, the placement of the lower top leadership position is carried out openly and competitively at the national or inter-regency / municipality in 1 (one) province.

\section{Qualitative Approach}

Patton in Ahmadi (2014: 15) stated "qualitative method is to understand the phenomenon that is happening naturally in the circumstances that are happening naturally. This concept emphasizes the importance of the nature of the data obtained, or natural data. The natural data is mainly derived from the direct expression of the subject of the researchers." Next, according to Denzin and Lincoln in Ahmadi (2014: 14) "the word qualitative emphasizes on the processes and meanings that are not tested or measured precisely in terms of quantity, amount, intensity or frequency".

In this study is conducted using qualitative and descriptive method with inductive approach. According to Bogdan and Biklen in Ahmadi (2014: 18) "the characteristics of qualitative method include: (1) naturalistic, (2) descriptive data, (3) attention to process, (4) inductive data analysis, and (5) meaning of life."

\section{DISCUSSION}

\section{Review of guidelines for the implementation} of top leadership position selection in local government

In accordance with the Regulation of the Minister of State Apparatus Empowerment (Permenpan) Number 13 of 2014, the selection and promotion for top leadership position must be conducted openly and competitively among civil servants based on the requirements of competence, qualifications, education and 
training, rank, track record, integrity and other requirements, with the aim to avoid from the motives of collusion, corruption and nepotism and to ensure the integrity of the state civil apparatus from political victims. The implementation of open promotion has been done since January 2012 for several promotions of positions such as Head of LAN, Head of State Personnel Board (BKN), Deputy of Archives Development of National Archives of the Republic of Indonesia (ANRI), Legal Expert Staff of the Ministry of State Apparatus Empowerment and Bureaucratic Reform (PAN RB). It is from here the milestone of the implementation of the selection and promotion of top leadership position in both Central and Regional Government.

The scope of the selection and promotion procedures of top leadership position in the government agencies include arrangements for preparation, implementation, monitoring, and evaluation of open promotion activities in central and local governments. The selection process starts from the preparation consisting of the formation of selection committee which is formed based on the proposal of the staffing officers of central or regional agency on the coordination and consideration of the State Civil Service Commission (KASN). Selection committee is a representation of the academics / professionals and the civil servants coming from related agencies or those who have relationships with the positions that will be filled. The number of selection committees must be odd number of at least 5 people and maximum 9 people with a maximum ratio of $45 \%$ coming from civil servants.

After the selection committee has been formed, all the information related to promotion of the position, such as qualifications, conditions, and other terms are announced through print and electronic media. For central government, higher and middle top leadership positions are announced nationally, and for lower top leadership position is announced at least at the ministry / institution level. Meanwhile, for middle top leadership position (in this case for local government, there is only 1 middle top leadership position, ie Provincial Secretary) the information is announced to all regencies / municipalities within the province. This procedure is also applied in the promotion for the lower top leadership position.

The next is the administrative selection stage which aims to see the requirements that must be fulfilled by the candidate, such as competence, qualifications, rank, education and training, job track record, integrity, and other requirements required by the position to be occupied. The selection committee determines at least 3 candidates, for every 1 vacant post, who are eligible for the competence selection stage. The competence selection consists of managerial competence and field competence. The competence selection is in the form of an assessment center or can also use psychometric methods, competence interviews, case analysis or presentations prepared according to the needs of office. The selection of field competence is conducted using written method, interviews, and other methods. As a final judgment, it can be added a final interview conducted by the selection committee related to the clarification of applicants that includes interest, motivation, behavior, and character. In addition, this can also involve elements of the users of the positions to be occupied.

Tracking of candidates relating to the track record of the position and experience to see the suitability of the positions applied for is done after all the selection processes have been completed. The aim is to make the record tacking as the main consideration instrument in determining candidates who are eligible to occupy a position. The tracking is conducted confidentially and objectively and has capability and technical knowledge of intelligence. And if it is deemed necessary, public tests can be conducted, especially for strategic positions. 
After the selection process is carried out, the Selection Committee announces the results of each stage to the participants and conveys the rating to the Staffing Officers confidentially. For the higher and middle top leadership position, the Selection Committee chooses 3 candidates with the highest ranting to be submitted to the Staffing Officer (Minister / Head of Institution / Governor). And for the lower top leadership position, the result is submitted to the authorized official. Next, the Staffing Officer (Minister / Head of Institution / Governor) proposes 3 (three) names of candidates for the higher and middle top leadership positions to the President. Meanwhile, for the lower top leadership position, the Authorized Official proposes 3 (three) names of candidates to the Staffing Officer (Minister / Head of institution / Governor / Regent-Mayor). Based on this matter the President issues a Presidential Decree to appoint higher and middle top leadership positions. And the Staffing Officer issues a decision to appoint lower top leadership position.

The monitoring and evaluation mechanism is carried out through the submission of a report on the selection of top leadership position openly to the State Civil Service Commission (KASN) and the copies are sent to the Minister of State Apparatus Empowerment and Bureaucratic Reform (PAN RB) for central agencies and the Minister of Home Affairs, and the Minister of State Apparatus Empowerment and Bureaucratic Reform (PAN RB)_for the regional institutions.

Based on the description of open promotion mechanism for top leadership position, especially on the scope of local government agencies, there are some things that become the concern because it can be a gap and provide space for corruption and other violations, such as on the stage of the formation of selection committee, the determination of the selection, and the implementation of monitoring and selection. When viewed from the side of the guidelines, the formation of the selection committee can be said to be fair if it includes the professional and the officials of civil servant. However, the concern is on the determination of the selection committee that is still in the hands of the Staffing Officers, or in this case, Governor and Regent / City Mayor for lower top leadership position in the region. So it is still prone to fraud. There is still possibility that the selection committee is the parties that have been set before. To overcome such a thing, it can be done by improving the function of State Civil Service Commission (KASN) so that in addition to giving consideration, KASN can also intervene in the determination of the selection committee, considering the importance of selection committee function in open promotion process of lower top leadership position in local government.

Another thing that becomes the concern is the mechanism of the determination of selection result for the lower top leadership position in the local government which is still in the hands of the Staffing Officer (Governor and Regent or Mayor). The President may provide warning or cancellation after receiving report / recommendation from KASN that will also report after receiving information from the selection committee.

Obviously this will take a considerable amount of time to find violations and nonconformity in the appointment of the lower top leadership position (JPT pratama), so there is a need for a simpler mechanism involving the central level in its determination. Likewise, KASN should directly handle and supervise the monitoring and evaluation mechanism reported by the Regional Staffing Officers, particularly on the implementation of the selection, so that KASN can play an active role when it is found irregularities.

\section{Asia Pasific Fraud Journal}

Volume 2, No.2 ${ }^{\text {nd }}$ Edition (July-December 2017) 
Figure 1

Promotion Mechanism of Lower Top Leadership Position in Local Government

\section{MEKANISME SELEKSI JPT PRATAMA DI DAERAH}

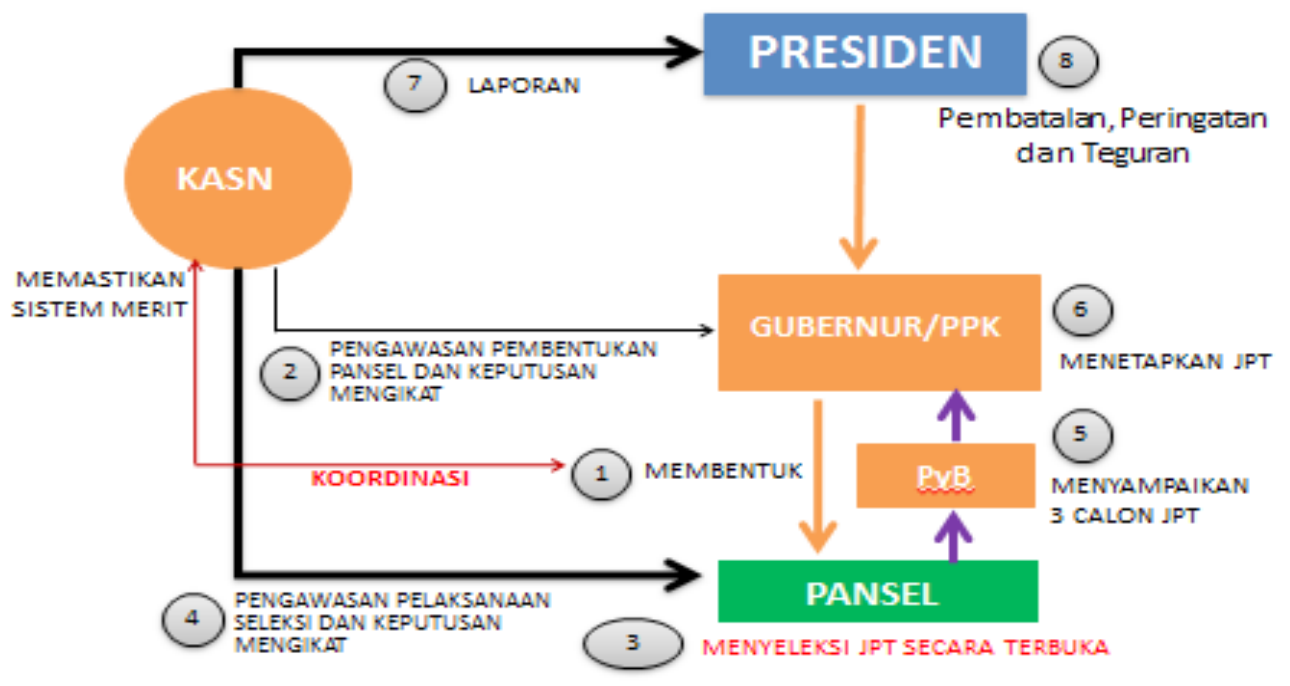

The improvement of an open selection system within the local government (an idea) Improvement of the top leadership position selection system should become a priority to be undertaken. This is related to the prevention of violations, such as collusion, corruption, and nepotism practices. Although the government, through KASN and PANRB Ministry, has sought to create a good guide, the improvement mechanism can be done using electronic system which is integrated to all parts of Indonesia. This will be able to assist the function of KASN in coordinating and overseeing the implementation of top leadership position (JPT) in the region. By using this developed electronic system, the KASN can also select and trace the track record of the candidates.

The electronic system used as a platform for the implementation of top leadership position (JPT) promotion throughout Indonesia can be named e-placement. Other functions that can assist the implementation of the tasks of KASN can be added in this system, such as in the search of data required in consideration related to either the selection committee or the candidates who will follow selection, so that all parties involved in the selection process already meet the criteria of competence and capabilities tailored to the needs of the top leadership position (JPT). Some functions that can be added are information function, selection implementation function and monitoring and evaluation function.

The information function can be expressed through the inclusion of all information related to the overall positions in which the placement must be conducted through open promotion throughout the territory of Indonesia, both central and local government, starting from the name of position, description of position, to the required qualifications. In other words, it can be said as the implementation of job analysis or job description. The aim is to provide the widest possible information to the candidates regarding the duties and positions that will be occupied. Another thing that needs to be added into the system is the provision of information related to all civil servants who have the potential to occupy a position. So, with 
the information, the basic data and additional data owned by candidates who come from civil servants can be known. For the problems related to the provision of data, that can be said to be very large, can utilize data on employment service application system (SAPK) belonging to the State Personnel Board (BKN) either central or regional and can also connect to the personnel management information system (SIMPEG) in each region. This will greatly support the work of KASN in overseeing all candidates who follow open promotions.

Through this site, the selection process can also be implemented integrally in one place so that the initial selection stage which is generally related to the selection of administration and initial competence can be monitored directly by the selection committee and also can be used as a medium for submitting any information related to the implementation of open selection, starting from the initial announcement to the determination of eligible candidates. With the mechanisms for the higher, middle, and lower top leadership positions at the central level, the opportunities are given to all eligible civil servants across Indonesia. And for the top leadership position at the provincial and regency / municipality level can only be followed by the civil servants of the region. In an effort to divide the task load, the e-placement site for the selection function can be divided into two domains, that is, for the higher, middle, and lower top leadership positions at the central level and at regional level.

Other functions that can be developed are those related to the supervisory function. In this case, the implementation of the supervisory or monitoring and evaluation function is not only related to the implementation of the selection, but also related to the implementation of duties for the candidates who have fulfilled all the criteria specified in a position. The supervision of the implementation of open promotion can involve parties from the State Civil Service Commission (KASN) and local governments so as to increase the active role of the KASN by not waiting for reports from local governments. The public monitoring mechanism, after being elected as the candidate who occupies a high position, is conducted through the test period or task orientation of at least for 6 months. The official must report all relevant programs and activities and deliver the results achieved publicly, so that the public can feel directly what the officials have actually done and provide advice or evaluation to the relevant government.

The application of electronic system or information system in the implementation of bureaucratic reform has been applied to other HR management functions such as on the selection function of the appointment of candidates for civil servant which is considered giving positive result. The civil servant selection system has been significantly reformed using a computerized approach called CAT (Computer Assisted Test) with three main functions that measure the basic competencies, state administration and personality of the participants. The civil servant selection fiscal year 2014 also had good value and there was an increase in the Public Perception Survey Index of Bureaucracy Reform 2014 implemented by the Minister of State Apparatus Empowerment and Bureaucratic Reform (PAN RB)_in collaboration with the survey institute. The survey was conducted in 12 big cities in Indonesia. The result of the survey of public perception regarding the selection of civil sevant has a value of 6.27 (Enough). This result, as explained above, has increased, ie in the first stage survey in 2014 the indicator of civil servant selection has a value of 4.94 (Somewhat Less Good). In addition, the determination regarding the number of positions to be filled through the civil servant selection is also conducted through an integrated electronic system known as e-formation. This system helps the government, in this case the Minister of State Apparatus Empowerment and 
Bureaucratic Reform (PAN RB), in making the determination and supervision of the needs of civil servants in all government agencies so as to avoid fictitious formations or nepotism.

Therefore, the application of civil servant selection and formation system using electronic system approach can change the image of bureaucracy to a better direction. This developed promotional system is also expected to be accepted and can accommodate the interests of all and most importantly is able to provide concrete evidence on the prevention of corruption. In addition, the function of the State Civil Service Commission (KASN), as the government party that has duties and functions in supervising the implementation of state civil apparatus management, should also be improved through the addition of supervisory function in every open promotion implementation and increase the number of competent personnel. It is because there is possibility that implementation of open promotion is conducted simultaneously in some government agencies as a consequence of the implementation of the simultaneous elections.

\section{Conclusion}

Based on the results of the discussion, there are several important points that could be used as suggestions for the implementation of open promotion for top leadership position in local government, including:

1. The need for a review, primarily related to the mechanisms and procedures for the implementation of open promotion for top leadership position in local government as well as the enhancement of the function and active role of the State Civil Service Commission (KASN), considering the risk of violations occurring in the local government without reducing the authority of the Governor and the Regent or the Mayor

2. The use of electronic system approach can be a solution in the implementation of open promotion for lower top leadership position in local government and can assist KASN in performing duties and functions as well as provide space to the public to participate in the implementation of open promotion in local government through direct supervision.

Some of the above analysis results do not intend to limit the authority and space of the Staffing Officer in the local government such as Governor and Regent/Mayor, but to achieve a promotion system that is free from collusion, corruption, and nepotism.

\section{REFERENCES}

\section{A. Books}

Ahmadi, Rulam. 2014. Metodologi Penelitian Kualitatif. Jakarta : Ar-Ruzz Media.

Ecip, S. Sinansari dan Sudarjat, Edi. 2015 Gerakkan Reformasi Birokrasi Kiprah Kementerian PANRB 2011-2014. Jakarta: Kementerian PANRB

Marwansyah. 2012. Manajemen Sumber Daya Manusia Edisi Kedua. Bandung : Alfabeta.

Rivai, Veitzhal. 2013. Manajemen Sumber Daya Manusia untuk Perusahaan dari teori ke praktik. Jakarta : PT.Raja Grafindo

Siagian, Sondang P. 2011. Manajemen Sumber

Daya Manusia. Jakarta : Bumi Aksara.

\section{B. Legislations}

Undang-Undang Nomor 5 Tahun 2014 tentang Aparatur Sipil Negara

Peraturan Pemerintah Nomor 13 Tahun 2002 Tentang Pengangkatan Pegawai Pada Jabatan Struktural

Peraturan Menteri Pendayagunaan Aparatur Negara dan Reformasi Birokrasi Nomor 13 Tahun 2014 Tentang Tata Cara Pengisian Jabatan Struktural yang 
Lowong Secara Terbuka di Lingkungan Instansi Pemerintah

\section{Others}

Majalah Layanan Publik Edisi L, Jakarta : 2014, Kementerian Pendayagunaan Aparatur Negara dan Reformasi Birokrasi

Profil Pendayagunaan Aparatur Negara 2013, Jakarta, : 2013, Kementerian Pendayagunaan Aparatur Negara dan Reformasi Birokrasi

Survei Persepsi masyarakat terhadap reformasi birokrasi 2014 : Kementerian Pendayagunaan Aparatur Negara dan Reformasi Birokrasi

www.menpan.go.id/berita-terkini/2013pengumuman-jadwal-pelaksanaan-tesseleksi-jabatan-eselon-2

www.menpan.go.id/berita-terkini/2748-dwiwahyu-atmaji-dilantik-menjadi-sesmenpanrb

www.menpan.go.id/berita-terkini/2983seleksi-terbuka-tak-harus-menunggu-pp

www.menpan.go.id/berita-terkini/2476kandidat-staf-ahli-ikuti-tes-penulisanmakalah reform there formers.org/ download/Reformasi\%20Birokrasi\%20 Bukan\%20Basa\%20Basi-\%20Studi\%20 Kasus\%20 Seleksi\% 20 Terbuka.pdf 